\title{
Isolation of Lumpy Skin Disease Virus Isolated from SPPV Vaccinated Cattle
}

\author{
Lutfi Bakar ${ }^{1}$ Ahmed S. Hussein ${ }^{2 *}$ Sabry M. Tamam² $\cdot$ Hanafy M. Madbouly²
}

Received: 03 May 2021 I Accepted: 24 August 2021 I Published online: 28 August 2021

1 College of Veterinary Medicine,
EL-Zawia University, Libya.
2 Department of Virology, Faculty
of Veterinary Medicine, Beni-
Suef University, Beni-Suef
62511 , Egypt.
Correspondence
Hussein AS, Department of
Virology, Faculty of Veterinary
Medicine, Beni-Suef University,
Beni-Suef 62511, Egypt.
Email: ahmadrahini@yahoo.com

\section{Introduction}

Lumpy skin disease (LSD) is a devastating viral transboundary high-impact cattle disease causing significant loss in production, Ochwo et al. (2018). It is characterized by fever, skin and visceral nodules as well as generalized lymphadenopathy and skin edema of affected animals, Coetzer (2004) as well as pneumonia as a common sequel with lesions in the respiratory tract, OIE (2010).

The disease is caused by a protype lumpy skin disease virus (LSDV) Neethling virus, as a member of genus Capripoxvirus in family Poxviridae, and subfamily Chordopoxvirinae Buller et al. (2005).
LSDV has double stranded DNA genome, encodes 30 homologues structural or nonstructural, viral proteins. It showed close antigenic relation to sheep pox virus (SPPV) and goat pox virus (GTPV) with nucleotide sequence identities of $96 \%$ among that species (Tulman et al. 2001; Tulman et al. 2002; Bhanuprakasha et al. 2006).

The LSD inducing severe economic losses due to decreased milk production, weight loss, poor growth, abortion, infertility and skin damage pneumonia, mastitis, infertility as well as mortalities especially in free areas (El-Bagoury et al. 1995; Irons et al. 2005; Salib and Osman 2011; Coetzer 2004; Babiuk et al. 
2008). In addition, the cost of treatment and control measures such as vaccination campaigns as well as indirect costs of the compulsory limitations in animal movement that causes significant financial losses on a national level (Tuppurainen and Oura 2012). The viral replication in cells such as the pericytes and endothelial cells in lymphatics and blood vessels walls; gives rise to vasculitis and lymphangitis. In some severe cases thrombosis and infarction may be the end result that cause edema in the affected areas (Vorster and Mapham 2008).

Laboratory diagnosis of LSDV can be performed by using serological techniques, PCR and by virus isolation in ECE and cell cultures, beside transmission electron microscopy, (OIE 2010).

Routine tests for LSDV diagnostics include molecular group methods for the detection of a CaPV, (Bowden et al. 2008; Stubbs et al. 2012; Haegeman et al 2013; Tuppurainen 2005; Balinsky et al. 2008).

Despite the implemented control measures, the disease is currently spreading widely in different governorates in Egypt in animals vaccinated with live attenuated sheep pox vaccine. Therefore, it was of importance to direct the aim of the present study to investigate the current status of LSDV in Beni-Suef Governorate, Egypt through isolation and molecular characterization of LSDV circulating in vaccinated cattle during 2017-2018.

\section{Materials and Methods}

\subsection{Cattle samples}

Twenty clinically suspected cattle showing typical signs for lumpy skin disease were used for collection of samples. Skin nodules biopsies were collected in sterile containers containing sterile phosphate buffer saline (pH 7.4) and also on 50\% glycerol saline.

\subsection{Virus isolation}

An amount of $0.2 \mathrm{ml}$ of the prepared tissue homogenate was inoculated on chorioallantoic membrane (CAM) of ECE (3 eggs for each sample). The inoculated ECEs were incubated for 6 days at $35^{\circ} \mathrm{C}$ and examined for presence of pock lesions. The CAMs from the first passage were kept at $-20{ }^{\circ} \mathrm{C}$ for next passage. Three serial passages were carried out by the same manner as in the second passages (Van Rooyen et al. 1969).

\subsection{Histopathological examination}

Sections from CAMs of the third passage were routinely examined. The tissue biopsies (preserved in $50 \%$ glycerol) were fixed in $10 \%$ buffered neutral formalin, paraffin embedded then stained with prior to their examination using light microscopy (Bancroft and Gamble 2002).

\subsection{Polymerase Chain Reaction (PCR)}

LSDV genome was extracted from the suspected material (tissue homogenate) and positive virus control using GF-1 tissue DNA extraction kit (Vivantis Technologies Malaysia) as described in the manufacture's instruction. Two virus positive controls were used including LSDV/Ismailia 88 strain and Sheep poxvirus vaccine were kindly supplied from a Pox Vaccine Production and Research Department, Veterinary Serum and Vaccine Research Institute (VSVRI), Abbassia, Cairo, Egypt. Amplification of target genes LSDV was carried out in a final volume of $25 \mu \mathrm{l}$. Two PCR reactions were conducted for each samples using two sets of pair specific primers flanking CRG and RPO30 genes (Table 1) according to Viljoen et al. (2005). The amplified DNA products were detected using agarose gel electrophoresis and DNA molecular weight marker.

Table 1. Oligonucleotide sequences used for the PCR amplification of LSDV.

\begin{tabular}{lll}
\hline Name & Gene-specific sequence primers & Amplicon size \\
\hline CRG* & LSD F 5' AGT ACA GTT AGT AGC GCA ACC-3' & 554 bp \\
& LSD R 5' GGG TGA ACT ACA GCT AGG TAT C- 3' & \\
\hline RPO30 & LSD F5'TCTATGTCTTGATATGTGGTGGTAG3' & 172bp \\
& LSD R5'AGTGATTAGGtGGTGTATTATTTTCC-3' & \\
\hline
\end{tabular}

*CRG: Coupled chemokine receptor gene. 


\section{Results}

\subsection{Clinical symptoms}

Recurrent outbreaks of suspected LSD in cattle population were observed during 2017-2018 at BeniSuef Governorate. Suspected cattle demonstrated skin nodules and scabs scattered all over the body. All the examined animals were vaccinated with a local modified live sheep pox vaccine before the occurrence of the disease with variable periods of 4-6 months

\subsection{Virus Isolation}

It was found that the inoculated samples induced lesions on CAMs by the $1^{\text {st- }}-4^{\text {th }}$ passages (Table 2). The collected CAMs showed hemorrhages, congested $\mathrm{BVs}$ by the $1^{\text {st }}$ passage. The pock lesions were detected in the form of white opaque large pock lesions and sometimes hemorrhagic which became more prominent at the $2^{\text {nd }}-4^{\text {th }}$ passages (Fig. 1a).

\subsection{Histopathological examination}

Histopathological examination of inoculated CAM with suspected LSD viral samples showed large eosinophilic intracytoplasmic inclusion bodies characteristic for Poxviridae (Fig. 1).

\subsection{Polymerase Chain Reaction (PCR)}

An extracted viral DNA from pooled CAMs of ECE was used for detection of LSDV using PCR. Primers specific for GPCR gene amplified a 554 bp product from LSDV genome confirming positivity of the sample for presence of LSD viral genome (Fig. 2) while primers set targeting RP030 gene amplified a $172 \mathrm{bp}$ product from LSDV genome confirming positivity of the sample for presence of LSD viral genome. Tissue culture adapted SPPV vaccinal strain amplified a (152 bp) which was easily distinguishable relative to the LSDV amplicons (Fig. 2).

Table 2. Positivity and intensity of pock lesions on CAM in different embryo passages.

\begin{tabular}{ccccc}
\hline \multirow{2}{*}{ Sample number } & \multicolumn{5}{c}{ Intensity of pock lesions in different embryo passages } \\
\cline { 2 - 6 } & 1st & 2nd & 3rd & 4th \\
\hline 1 & - & + & + & ++ \\
\hline 2 & - & + & + & ++ \\
\hline 4 & + & + & ++ & ++ \\
\end{tabular}

- No growth + white opaque pock lesion, + + Large hemorrhagic pock lesion

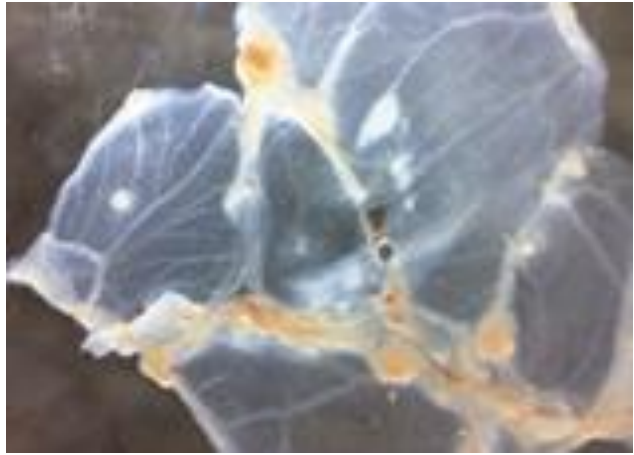

(a)

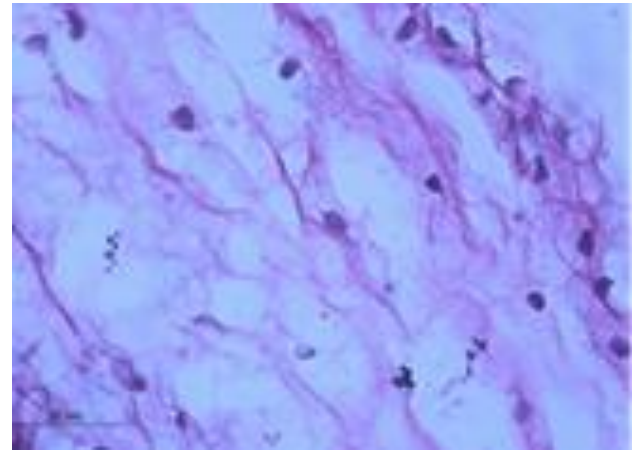

(b)

Fig. 1. Gross and histopathology of CAM inoculated with skin homogenate from diseased cattle with skin lesion (a) Characteristic pock lesions of infected CAM (b) Stained inoculated CAM showing eosinophilic intracytoplasmic inclusions (H and E 100X, oil emersion lens). 


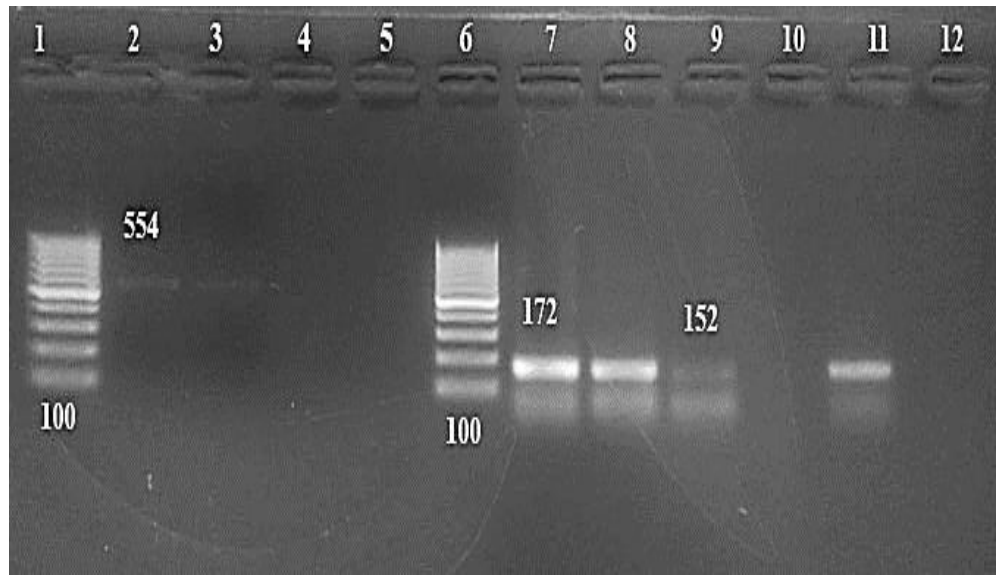

Fig. 2. Gel electrophoresis of PCR products using two LSDV specific primers, Lane 1 and 6: 100 bp DNA ladder, lane 2 and 3: LSDV suspected samples (554 bp), lane 4 and 5: sample pools showed negative results. Lane 7, 8 and 11: samples showed positive result (172 bp), lane 9: sheep pox vaccine (152), lane 10: control negative sample, Lane 11: control positive sample.

\section{Discussion}

Massive outbreaks of LSDV in cattle population were observed during 2017 and 2018 at Beni-Suef governorate. Animals were vaccinated before the occurrence of the disease with variable periods of 4-6 months. These outbreaks were observed in previously vaccinated cattle with the Romanian sheep poxvirus (SPPV) vaccine. The appearance of these outbreaks in vaccinated cattle become a questionable and raises the concern of the efficacy of the SPPV vaccine. A study conducted by (Elkady 2016) showed that animals suffered from severe signs differed from that reported in the previous LSD outbreaks, in terms of severity and deaths at different governorates including BeniSuef governorate.

LSD suspected cattle showed multiple localized or generalized skin nodules. Skin lumps varied in size but were mostly $1-3 \mathrm{~cm}$ in diameter and were quite hard in consistency and affected the full thickness anywhere on the animal body. Similar lesions appeared in the mucosa of the mouth, nose, vagina and conjunctiva. A circular dark line of necrosis appeared around the surface of the lesions and produced the 'sit-fast' that is so typical of the disease. Central necrotic plug eventually sloughed and left a raw granulating ulcer or pock. Such findings were similar to the clinical manifestation of LSD previously described by (Awad et al. 2009; Abdelwahab 2016; Elkady 2016). Skin lesions were preceded by fever. Edema in the legs and brisket was observed in many cases. The observed edema may be explained on the basis of the basic pathogenic mechanism by which the LSDV seems to cause lesions is viral replication in cells such as the pericytes and endothelial cells in lymphatics and blood vessels walls; giving rise to vasculitis as reported by Vorster and Mapham (2008).

Abdallah et al. (2018a) reported sporadic cases of LSD in cattle previously vaccinated with Romanian SPPV vaccine in Sharkia Governorate. The present study confirmed the isolation of LSDV from skin lesions of cattle on the CAM of -ECE and the virus nucleic acid was identified in the conventional PCR using two different pairs of primers.

For clarifying the reasons of reappearance of LSDV among cattle previously vaccinated with the Romanian live attenuated sheep pox virus vaccine, skin nodules from clinically diseased cattle were collected as aseptically as possible and used for isolation of the virus. Skin lesions have been reported to be the most useful samples for virus isolation (Bowden et al. 2008) because the virus can be isolated for up to 35 days after the first appearance of the skin nodules (Tuppurainen 2005; Wiess 1968). In the current study, the lesions observed of CAMs after inoculation of the LSDV agree with (Hamoda et al. 2002; Ahmed et al. 2005; Tamam 2006; ElKenawy and El-Tholoth 2009) who observed pock lesions on CAMs of inoculated ECEs and the pock lesions of the virus became clearer after serial passages. The development of lesions on CAM was firstly detected by (Alexander et al. 1957; Van 
Rooyen et al. 1969) and varied from thickening and congestion (El-Kenawy and El-Tholoth 2011) to clearly visible pock lesion (House et al. 1990) that looked like numerous, small, scattered white foci (ElNahas et al. 2011).

Histopathological examination of infected CAMs showed characteristic eosinophilic intracytoplasmic inclusion bodies characteristic for poxviridae appeared in ectodermal cell and mesodermal cell layers of CAM infected with suspected LSD viral sample and stained hematoxylin and eosin. These inclusions were suggestive for the presence of LSDV as a member of capripoxviruses replicating in the cytoplasm. Such results agree with those reported by (Tamam 2006; Sohier et al. 2008; Abdelwahab 2016; Elkady 2016) who observed formation of intracytoplasmic inclusion bodies which indicate extensive replication of LSDV.

For molecular identification, an extracted viral DNA from pooled CAMs of ECE was used for detection of LSDV with PCR. Two types of Oligonucleotide primer pairs were used for detection of the local LSDV strain in infected CAM. The first primer was specific for GPCR gene which is expected to amplify the specific product $554 \mathrm{bp}$. The second primer targeted the LSDV RP030 gene which is expected to amplify the specific product $172 \mathrm{bp}$ from the extracted DNA products using PCR.

Primers specific for GPCR gene amplified a $554 \mathrm{bp}$ product from LSDV genome confirming positivity of the samples for presence of LSD viral genome (photo 3) while primers set targeting RP030 gene amplified a 172 bp product from LSDV genome confirming positivity of the samples for presence of LSD viral genome. Tissue culture adapted SPPV vaccinal strain amplified a (152 bp) which was easily distinguishable relative to the LSDV amplicons, photo (3). The PCR proved to be a specific assay for specific detection of LSD virus in skin lesion (Stram et al. 2008; ElNahas et al. 2011), CAMs and cell culture (El-Kholy et al. 2008; El-Kenawy and El-Tholoth 2011), semen (Bagla et al. 2006) and blood and skin samples (Tuppurainen et al. 2005). PCR assay in this study provides a very cooperative technique and could easily distinguish between these viruses going to a clear cut between them even at low concentration of the virus in field sample as reported by Stram et al. (2008).
In Egypt, the vaccination policy adopts Romanian sheep pox vaccine strain and a Kenyan sheep pox tissue culture vaccine strain produced in Vero cell line ((Davies 1991; Michael et al. 1994). Meanwhile, the live modified lumpy skin disease virus vaccine (Ismailia strain) was produced and proved to be safe, potent and able to protect cattle against challenge with virulent LSDV (Daoud et al. 1998; Abdelwahab et al. 2016). On the other hand, inactivated LSDV vaccines were prepared and evaluated (Saber et al. 2000; El-Desawy 2001). LSDV vaccine adjuvanted with Nigella sativa oil was safe and elicited high antibody response against LSD either when used alone or in combination with sheep pox vaccine (Madbouly et al. 2002). In contrast, the Romanian sheep poxvirus (SPPV) vaccine is still used in spite of the appearance of the disease in cattle vaccinated with this vaccine that showed low protection and leading to sever economic losses.

\section{Conclusion}

In conclusion, LSDV infections have been detected and the virus has been isolated and identified by PCR from cattle previously vaccinated with SPPV during the summer of 2018 in Beni-Suef. Evaluation of the vaccine efficacy under field conditions is necessary to select the most effective and protective vaccine.

\section{Conflict of interest}

The authors declare no conflict of interest.

\section{References}

Abd El-Rahim IHA, El-Balal S, Hussein M (2002). An outbreak of lumpy skin disease among cattle in Upper Egypt (El- Menia Governorate). $2^{\text {nd }}$ Sci. Cong Fac Vet Med Minufya Univ., 185-200.

Abdelwahab MG, Khafagy HA, Moustafa AM, Saad MA (2016). Evaluation of humoral and cell-mediated immunity of lumpy skin disease vaccine prepared from local strain in calves and its relation to maternal immunity. J Am Sci., 21: 38-45.

Ahmed LA, El-Desawy OM, Mohamed AT (2005): Studies on bovine field skin lesions in Fayoum Governorate. Vet Med J Giza, 53(1): 73-81.

Alexander RA, Plowright W, Haig DA (1957). Cytopathogenic agents associated with LSD of cattle. Bull. Epiz Dis Afr., 5: 489-492.

Awad WS, Ibrahim AK, Mahran K, Fararh KM, Abdel Moniem MI (2009): Evaluation of different diagnostic methods for diagnosis of Lumpy skin disease in cows. Springer Science Business Media B.V. 
Babiuk S, Bowden T, Boyle D, Wallace DB, Kitching $R$ (2008). Capripoxviruses: An emerging worldwide threat to sheep, goats and cattle. Transboundary and Emerging Diseases, 55(7): 263-272.

Balinsky CA, Delhon G, Smoliga G, Prarat M, French RA, Geary SJ, Rock DL, Rodriguez LL (2008). Rapid preclinical detection of sheep pox virus by a realtime PCR assay. J Cli. Microbiol., 46(2): 438-442.

http://dx.doi.org/10.1128/jcm.01953-07.

Bancroft JD, Gamble M (2002). Theory and practice of histological techniques. $5^{\text {th }} \mathrm{Ed}$ Edinburgh Churchill Livingstone Pub., 172-175, 593-620.

Bhanuprakasha V, Indranib BK, Hosamania M, Singha RK (2006). The current status of sheep pox disease. Comp. Immunol Microbial Infect Dis., 29: 27-60.

Bowden TR, Babiuk SL, Parkyn, G. R, Copps JS, Boyle DB, (2008). "Capripoxvirus tissue tropism and shedding: a quantitative study in experimentally infected sheep and goats." Virology, 371(2,): 380-393.

Buller RM, Arif BM, Black DN, Dumbell KR, Esposito JJ, Lefkowitz EJ, McFadden G, Moss B, Mercer AA, Moyer RW, Skinner MA, Tripathy DN (2005). "Family poxviridae," in Virus Taxonomy: Classification and Nomenclature of Viruses. Eighth Report of the International Committee on Taxonomy of Viruses,

Fauquet CM, Mayo MA, Maniloff J, Desselberger U, Ball LA , Eds., 117-133, Elsevier Academic Press, San Diego, Calif, USA.

Burdin ML, Prydie J (1959). Observations on the first outbreak of LSD in Kenya. Bull Epiz Dis Afr., 7: 21-26.

Coetzer JAW (2004). Lumpy skin disease. Oxford University Press Southern Africa, 2: 1268-1276.

EL-Bagoury GF, Madbouly HM, Iman AA Farrag, Saber MS (1995). Isolation and characterization of Lumpy skin disease (LSD) virus from cattle during natural outbreak in Minia governorate. Proceeding of the first Scientific Conference for Vet Sci., 11(2): 167-174.

El-Desawy OM (2001). Studies on lumpy skin disease virus vaccine. Department of Virology. Ph.D. Thesis, Fac. Vet. Med. Cairo Univ.

Elkady GHM (2016). Studies on Lumpy Skin Disease Virus. MVSc (Virology) Thesis. Department of Virology, Faculty of Veterinary Medicine, Benha University.

El-Kenawy AA, El-Tholoth MS (2009). Isolation and Identification of lumpy skin disease virus from cattle on chorioallantoic membranes (CAMs) of fertile eggs. Mansoura Vet Med J., 6: 131-139.

El-Kenawy AA, El-Tholoth MS (2011). Lumpy Skin Disease Virus Identification in Different Tissues of Naturally Infected Cattle and Chorioallantoic Membrane (CAMs) of Embryonated Chicken Eggs Using Immunofluorescence, Immunoperoxidase techniques and Polymerase Chain Reaction. Int J Virol., 7(4): 158166.
El-Kholy AA, Soliman HMT, Abdelrahman KA (2008). Polymerase chain reaction for rapid diagnosis of a recent lumpy skin disease virus incursion to Egypt. Arab J Biotech., 11(2): 293-302.

EI-Nahas EM, El-Habbaa AS, El-Bagoury GF, Radwan MEI (2011). Isolation and Identification of Lumpy Skin Disease Virus from Naturally Infected Buffaloes at Kaluobia, Egypt. Global Veterinaria, 7(3): 234-237.

Esposito JJ, Ferner F (2001). Poxviruses. In: B.N. Fields D.M. Knipe, P.M. Howley, R.M.

Haegeman A, Zro K, Vandenbussche F, Demeestere L, Campe W, Van Ennaji MM, De Clercq K (2013). Development and validation of three Capripoxvirus real-time PCRs for parallel testing. J Virol Methods, 193(2): 446-451.

http://dx.doi.org/10.1016/j.jviromet.2013.07.010.

Hamoda FK, Aboul-Soud EA, Magda MS, Shahein MA, Michael A, Daoud AM (2002). Field and laboratory studies on lumpy skin disease. J Egypt Vet Med Ass., 62(5): 183-199.

House JA, Wilson TM, El-Nakashly, S, Karim IA, Ismail I, El-Danaf N, Moussa AM, Ayoub NN (1990). The isolation of LSD- virus and bovine herpes virus-4 from cattle in Egypt. J Vet Diagn Invest., 2: 111-115.

Irons PCE, Tuppurainen SM, Venter EH (2005). "Excretion of lumpy skin disease virus in bull semen." Theriogenology, 63(5): 1290-1297.

Madbouly HM, Fatehia MM, El-Desawy OM, Tamam SM (2002). Comparative efficacy of sheep pox virus (SPV) vaccine in cows at different stages of pregnancy and in young calves for controlling of lumpy skin disease. $10^{\text {th }}$ Sci Conf Fac Vet Med Assuit Uni., 17-19 December 2002

Ochwo S, VanderWaal K, Munsey A, Ndekezi C, Mwebe R, Okurut ARA, Nantima N, Mwiine FN (2018). Spatial and temporal distribution of lumpy skin disease outbreaks in Uganda (2002-2016). Vet Res., 14(1): 174.

OIE (2010). Lumpy Skin Disease, Chapter 2.4.14 OIE Terrestrial Manual, Office International des Epizooties, Paris, France.

Salib FA, Osman AH (2011). Incidence of lumpy skin disease among Egyptian cattle in Giza Governorate, Egypt. Veterinary World, 4(4): 162-167.

Sohair IB, Ibrahim EM, Shahein MA (2008). Virological and pathological studies on lumpy skin disease in naturally infected cattle. Egypt J Comp Path, Clinic Path., 21(1): 446- 465.

Stram Y, Kuznetzova L, Friedgut O, Gelman B, Yadin H, Rubinstein-Guini M (2008). The use of lumpy skin disease virus genome termini for detection and phylogenetic analysis. J Virol Meth., 151(2): 225-229. 
Stubbs S, Oura CAL, Henstock M, Bowden TR, King DP, Tuppurainen ESM (2012). Validation of a highthroughput real-time polymerase chain reaction assay for the detection of capripoxviral DNA. J Virol Methods, 179(2): 419-422.

Tamam SM (2006). Isolation of lumpy skin disease virus from naturally infected cattle previously vaccinated with live attenuated sheep pox virus vaccine. Bs Vet Med J., 16(1): 27-31.

Thomas AD, Mare CVE (1945). Knopvelsiekte. J S Afr Vet Med Assoc., 16: 36-43.

Tulman ER, Afonso CL, Lu Z, Zsak L, Kutish GF, Rock DL (2001). Genome of lumpy skin disease virus. J Virology, 75(15): 7122-7130.

Tulman ER, Afonso CL, Lu Z, Zsak L, Sur JH, Sandybaev, NT, Kerembekova UZ, Zaitsev VL, Kutish GF, Rock DL (2002). The genomes of sheep pox and goat pox viruses. J Virol., 76(12): 6054-6061.

Tuppurainen ESM (2005). The detection of lumpy skin disease virus in samples of experimentally infected cattle using different diagnostic techniques. MVSc Thesis, Fac Vet Sci Univ Pretoria.
Tuppurainen ESM, Oura C (2012). Review: Lumpy skin disease: An emerging threat to Europe, the Middle East and Asia. Transboundary and Emerging Diseases, 59(1): 40-48.

Van Rooyen PJ, Munz EK, Weiss EK (1969). The optional conditions of Neethling-type lumpy skin disease virus in embryonated eggs. R. Vet. Res., 2: 165-174.

Viljoen GJ, Nel LH, Crowther JR (2005): Molecular diagnostic PCR handbook. IAEA-FAO, Springer, Dordrecht, Netherlands

Vorster JH, Mapham PH (2008). Lumpy skin disease. Livestock Health and Production Review. Jaargang 10/1: 16-21.

Weiss KE (1968). Lumpy skin disease virus. Virol Monogr., 3: 111-131.

How to cite this article: Bakar L, Hussein AS, Tamam $\mathrm{SM}$, Madbouly HM. Isolation of lumpy skin disease virus isolated from SPPV vaccinated cattle. J Vet Med Res., 2021; 28(1): 38-44.

https://doi.org/10.21608/jvmr.2021.73921.1037 